thigh in other lands than India, I may say that I have observed the same mode of operating upon paper in Japan very frequently. The paper used there is tough and fibrous, and a Japanese is never at a loss for card to tie a parcel with if he has paper beside him. I have seen the spindle-whorl in actual use in upland districts, and it was employed even in Tokio very recently.

Laurel Bank, Shawlands, Glasgow, April 7 Henry Fauldo

\section{Colony of Cats}

IT may interest those of your readers fond of cats to know that a colony of cats live and breed under the wooden platform of the Victoria Station of the District Railway. They may be seen crossing the rails right in front of trains, and considering the enormous traffic, and the consequent noise and vibration, it certainly does seem remarkable that such naturally timid animals as cats should live amidst such unnatural surroundings. It may tend to show the plasticity of the animal creation generally in adapting itself to surrounding conditions. A female cat may have taken refuge there originally, and hence the railway domestication of the animals.

London George Rayleigil Vicars

\section{Earthworms}

SEEING the correspondence on this subject, I am led to give the following fact, which affords a further proof of the necessity of a vegetable deposit being formed previous to the existence of earthworms as stated by Mr. Melvin (vol. xxix. p. 502). A field two years ago was converted into a garden, and on accuunt of bad cultivation, and by reason of each crop being altogether removed for several years in succession, no worms were there, but after the application of a large quantity of stable manure worms have appeared by hundreds, and their castings after rain afford ample proof of their activity. TRANsformation of vegetable mould combined with animal refuse into available food for plants is here made evident.

Driffield, April 7

\section{"The Axioms of Geometry"}

Prof. HenRICI, in NatuRe, vol. xxix. p. 453, considers Hamil ton's proof of Euclid I. 32 invalid ; and asserts that from his reasoning it would follow that the sum of the three angles of a spherical triangle equals two sight angles. I venture to differ from him for the following reason:-The only thing which Hamilton requires to be granted is that when a moving straight line slides along a fixed straight line its direction is unchanged. This axiom will, I suppo: $e$, be granted by every one. Of course it is not true that in every case rotation is independent of trans lation. But Hamilton's proof does not require it to be true in every case, but only in the case of a straight line. Hence I maintain that Hamilton's reasoning is perfectly correct, and his proof valid.

Bardsea, March 26

\section{GEOLOGY OF CENTRAL AFRICA}

$T \mathrm{HE}$ following extract from a letter received by $\mathrm{Mr}$. Geikie from Mr. Henry Drummond, who is at present exploring the Lake region, may interest our readers :-

\section{"Maramoura, Central Africa, November I, 1883}

"I have now completed a traverse from the mouth of the Zambesi, by way of the Shire highlands, in a northwest direction, until the line joins Mr. Joseph Thomson's route, about half way between Lakes Nyassa and Tanganyika. I have filled in the geology so far as is possible in a single survey, and hope thus to be able to extend the sketch geological map, begun by Thomson, for some distance south and west. I may still further extend this by an expedition to Lake Bangweolo, after the rainy season, but there are circumstances which may make it necessary for me to leave for home in February or March. Perhaps the most interesting thing I have to note is the discovery here of a small but rich bed of fossils. The strata alluded to consist of light coloured limestones and shales, with beds of fine gray sandstones, and the fossils include plant, fish, and molluscan remains. Plants are the most scarce, but fish-scales and teeth exist in vast numbers. Unfortunately whole fish are extremely rare, and after three or four days' search I have only succeeded in securing two or three indifferent specimens. The mollusks, on the other hand, are obtainable in endless quantity, and are in fine preservation. Indeed there is one small bed of limestone entirely made up of these remains, all, however, belonging to a single species. From the general character of the beds I am inclined to think they are of lacustrine origin. These fossiliferous beds are the only sedimentary rocks I have crossed between the mouth of the Shire-say I 30 miles from the coast-and the centre of the Nyassa-Tanganyika plateau. At the point where I crossed them they are not more than a couple of miles in breadth, and are flanked on either side by granite and gneiss. They lie at a short distance from Lake Nyassa, and are probably part of the Mount Waller series. This series stretches for some short distance along the north-west shore of the lake, but is apparently of no great extent. These deposits may possibly throw some light on the problem of the lake.

"As regards the controversy between $\mathrm{Mr}$. Thomson and Mr. Stewart about (I) the Livingstone Mountains, and (2) the bed of iron between the lakes, I should say that on both points both explorers are right from their own point of view.

"Mr. Stewart had only been dead a few days when I reached the north end of Nyassa. It was a great disappointment and blow to me, as I looked forward to much help from him. No one living possesses anything like his knowledge of the physical geography of this part of the interior."

\section{CHINESE PALAENTOLOGY}

PAL $2 O N T O L O G Y$ is not a study that commends itself to the attention of Chinamen. With archæology the case is different. That is a pursuit which within historical limits the Chinese follow with enthusiasm. Every one who possesses any pretensions to culture, and who can afford to indulge the inclination, collects all that is old from cracked china to coins. So prevalent is this taste, and so keen is the competition for objects bearing the stamp of age, that a flourishing trade, such as rivals the celebrated traffic in "antiquities" carried on at Jerusalem, exists in fabricated antiques for the benefit of inexperienced native collectors and foreign purchasers. But natural antiquities are, speaking generally, left unnoticed, or if thought of for a moment are hastily explained by random conjectures. Topsy's celebrated explanation of her existence is about on a par with the guesses which are hazarded by the most learned Chinamen to account for palæontological phenomena. Science has always a borderland of unsolved questions, but in China this borderland exceeds in extent the territory of knowledge in the possession of the people. They have no aptitude for palæontology, and few writers make any reference to it. Among the rare exceptions to this rule is Ch'ên Kwah of the Sung Dynasty (A.D. 960-1127), who, in an interesting work entitled "Notes from a Dreamy Valley," has collected a number of facts on natural antiquities as well as on other matters. His knowledge is not ceep, but when we remember that Voltaire accounted for the presence of marine sbells on the top of the Alps by supposing that pilgrims in the Middle Ages had dropped them on their way to Rome, a great deal may be forgiven a Chinese writer of the eleventh century.

The Chinese have so completely lost sight of the possibility of the existence in China of any civilisation but their own that when they meet with traces of earlier man they attribute them either to blind chance or to 
supernatural causes. In this way when $\mathrm{Ch}^{\prime}$ 'ên Kwah met in the course of his investigations with flint and bronze implements he at once adopted the common opinion of his countrymen, which is the same as that which was prevalent in Europe a couple of centuries ago, that they were thunderbolts shot down by the God of Thunder in the explosions of his wrath. In confirmation of this theory Ch'ên states that though these implements are found all over the country they are more plentiful in districts, such as Lui-chow in the province of Canton, where thunderstorms are more than usually prevalent. In shape, he tells us, they resemble axes, knives, small hammers several pounds in weight, skewers or nails, and other pointed implements. In colour they vary, some being yellow, some green, and some black. Some of the axesbaped stones are bored with two boles, but the majority are not pierced, and implements of the same shape are found in bronze and irorr.

Speaking within his own knowledge he only describes the circumstances of the discovery of two stone axes, both of which he tells us were found beneath trees. In one case, at Sin-chow, in Hupeh, after a severe thunderstorm in which, like Prospero, the God of Thunder had

$$
\text { "With his own bolt," }
$$

a stone axe was found at its roots; and on another occasion at Sui-chow, under precisely similar circumstances, a shepherd-lad found a "fire stone in the shape of an axe." As in the only two cases about which Ch'ên speaks from personal knowledge the axes were found beneath trees, it is not unnatural to suppose that they are more frequently found in that position than elsewhere; and this becomes interesting when we find it stated by Mr. Rivett Carnac in a valuable paper published in vol. lii. of the Procectings of the Bengal Branch of the Royal Asiatic Society, that it is the custom in Central India for the finder of a stone axe or other stone implement to place it "under the village pipul tree," and sometimes to sanctify it with a daub of red paint, and thus to constitute it a Mahadeo. A somewhat similar practice exists, according to Chinese historians, in a country vaguely described as being to the west of the Yub Pass in Chinese Turkestan, where "thunder stones" when found are deposited in the temples. May not this Indian practice have also been the custom of some of the aboriginal tribes of China? and may not the fact that in the two instances mentioned above the axes were found at the roots of riven trees be evidence of the antiquity of the custom, as in cases described by Mr. Rivett Carnac, in which the roots of the trees and the surrounding soil had in course of years so completely grown over the axes that they could only be cut and dug out with difficulcy?

Stone arrow-heads do not seem to have come within Ch'èn's range of observation, although from historical references we know that they are to be met with in China. In the "Book of History," which is said to have been compiled by Confucius, mention is made of tribute, consisting of iron, silver, steel, and stone arrow heads, having been presented to the Chinese Court by the tribes on the Yellow River about the year 2200 13.C. The story is told also that on one occasion, as the Prince of Ch'ên (495 B.C.) was walking in the palace grounds, a bird fell dead at his feet, pierced through by a stone-headed arrow. As the kind of bird was unknown to the prince and his courtiers, Confucius was called in to give his opinion upon it. The bird he pronounced to be a species of sparrow-hawk from Northern Tartary, and he explained $t$ at the stone head which pointed the dart was similar to that which $\mathrm{Wu}$ Wang (B.C. II22) presented to his prince. It appears als, that stone arrow-heads were used in incient times as emblems of authority, and that they have very commonly been presented to sovereigns as objects of curiosity and value.
The biographical dictionaries tell us that in course of his official duties Ch'ên was called upon to direct extensive irrigating works; and no doubt the excavations and cuttings which he then superintended led him to take an interest in the fossil remains with which the country abounds. On this subject he has many notes. In one he tells us that at a certain spot on the Yellow River, the banks having fallen away for a considerable distance, a fossil bamboo grove was disclosed, a fact which excited his surprise, as the district is not one in which bamboos grow at the present day, and he contrasts with this the fossil peach-stones, roots of rushes, snakes and crabs, which are found at the Kin-hwa Mountain, all of which things are still indigenous in the neighbourhood. At Tsêh-chow in Shansi, he states, a man, when digging a well, suddenly unearthed a "lizard resembling a dragon." At sight of the monster the man fled in terror, but observing from a distance that it remained motionless, he ventured to return, when, to his relief, he found that it was petrified. Philistine-like, his neighbours broke it to pieces, and only one bit of it was preserved. Another kind of fossil has long been a puzzle to the philosophers, from the great and wise emperor, K'ang-hi (I66I-I720), downwards. Adventurous travellers who have braved the northern frosts have from time to time brought back accounts of the mammoths which are found in the frozen cliffs of Siberia. Deceived by a mistaken analogy, the Chinese wiseacres have arrived at the conclusion that these monsters must be huge ivory-producing rats, and, misinterpreting their continued preservation, have formed the opinion that darkness is necessary to their life, and that exposure to the outer air produces instant death. Their ivory is considered to be softer than elephant ivory, and in the hands of skilful chemists their flesh is said to make up into a highly invigorating tonic.

Speaking of the neighbourhood of the Loh River, Ch'ên mentions the discovery of ancient Troglodyte dwellings in which were found coins, and in one case a stone chest bearing on the outside fine tracings of flowers, birds, and other objects. Un the lid were inscribed upwards of twenty characters, which were of such an archaic form that they were undecipherable. But the contents were ea sily understood, and were at once recognised as pieces of pure gold.

Constant mention is made by Ch'ên of meteoric stones, which in popular imagination are said to assume various strange and uncanny forms. Of the desceni of one such stone which fell in the province of Kiang-su in the year 1064, he gives certain particulars on the authority of a Mrs. Heu. This lady, when in her garden one day, was startle 1 by an explosion like a peal of thunder, and saw a large "star nearly as big as the moon" pass across the sky from south-east to south-west, and eventually fall within a few yards of the place where she was standing. On going to the spot she observed a deep hole, at the bottom of which was the "star shining brightly." By degrees the light died away, and eventually at a depth of three feet she dug up a round stone of the size of a man's fist, and of the weight and appearance of iron. Altogether Ch'ên's work is well worthy of the study of those who can read Chinese and who are interested in the palæontology of China.

ROBERT K. DOUGLAS

\section{ON THE FORMATION OF STARCH IN LEAVES}

$\mathrm{N}$ a recent communication to the Arbeiten des botanisches Institut in Würzburg (Bd. iii.), Prof. Sachs gives the results of his work during the past summer in connection with the above subject. The investigations were made with the object of determining the formation and disappearance of starch in the leaves of plants growing in the open, and under normal conditions of vegeta- 